\title{
Ageing of black carbon along a temperature gradient
}

\author{
Chih-Hsin Cheng ${ }^{\mathrm{a}, \mathrm{b}, *}$, Johannes Lehmann ${ }^{\mathrm{a}}$ \\ ${ }^{a}$ Department of Crop and Soil Sciences, Cornell University, Ithaca, New York 14853, USA \\ ${ }^{\mathrm{b}}$ School of Forestry and Resource Conservation, National Taiwan University, Taipei 106, Taiwan
}

\section{A R T I C L E I N F O}

\section{Article history:}

Received 13 November 2008

Received in revised form 12 January 2009

Accepted 13 January 2009

Available online 14 February 2009

\section{Keywords:}

Black carbon

Ageing

Surface charge

Surface functional groups

Adsorption

\begin{abstract}
A B S T R A C T
Black carbon (BC) is regarded as a chemically and biologically stable form of carbon and the changes of BC properties in nature are generally assumed to be minute. However, more and more observations have argued the inertness of $\mathrm{BC}$. The objectives of this study were to characterize the changes of $\mathrm{BC}$ properties through ageing processes and to identify if these changes are associated with temperature. Our results showed that ageing of $\mathrm{BC}$ occurs over a temperature range from $-22{ }^{\circ} \mathrm{C}$ to $70{ }^{\circ} \mathrm{C}$ within a short period of 12 months. The main changes of BC properties through ageing were found in elemental composition, surface chemistry, and adsorption properties, where the aged BCs were shown to have higher oxygen concentrations, surface acidity, and negative surface charge but lower $\mathrm{C}$ concentrations, pH, surface basicity, point of zero net charge, and also a lower adsorption capacity of hydroquinone, an allelopathic compound, than fresh $\mathrm{BC}$. These ageing processes of $\mathrm{BC}$ were affected by temperature and changed over time, with higher temperature and longer incubation time enhancing $B C$ ageing. Our results from a wide temperature range suggest that ageing of $\mathrm{BC}$ is likely to occur in any terrestrial regime and that the changes of $\mathrm{BC}$ properties through ageing should not be overlooked.
\end{abstract}

(c) 2009 Elsevier Ltd. All rights reserved.

\section{Introduction}

Black carbon (BC) is a residue of incomplete combustion of biomass and fossil fuel. Because of the thermal alteration of its structure, BC is regarded as a chemically and biologically stable form of carbon (C) and can persist in nature over long periods of time (Goldberg, 1985; Schmidt and Noack, 2000). Often, mineralization of $\mathrm{BC}$ is considered to be negligible. Archaeologists use the refractory properties of BC for dating deposits (Bird et al., 2002) and ecologists for evaluating past fire events (Korhola et al., 1996).

An increasing number of observations, however, have questioned the inertness of BC (Czimczik et al., 2003; Murage et al., 2007) and argued that $B C$ properties could change, for example, by oxidation (Cheng et al., 2006, 2008a). These "ageing processes" of $\mathrm{BC}$ may have profound influences on its basic physicochemical properties, such as elemental composition (Cheng et al., 2006), hydrophilicity (Leon y Leon et al., 1992), and amphotericity (Lau et al., 1986). Thus, in addition to intrinsic differences due to its charring conditions or different precursors, it is likely that ageing of BC can additionally alter BC properties and then affect BC's biogeochemical properties. The understandings of $\mathrm{BC}$ ageing and the associated changes in $\mathrm{BC}$ properties including adsorption of natural

\footnotetext{
* Corresponding author. Address: School of Forestry and Resource Conservation, National Taiwan University, Taipei 106, Taiwan. Tel.: +8862 33664620.

E-mail address: chengch@ntu.edu.tw (C.-H. Cheng).
}

compounds are still scarce and more detailed information is required.

The central issue in understanding $\mathrm{BC}$ ageing is to know how environmental factors affect the ageing processes. Temperature and time of exposure are likely to be major factors influencing BC ageing as shown by several studies (Puri, 1970; Cheng et al., $2006,2008 \mathrm{a}$ ). It is less clear, how BC aging responds to a wide gradient of temperature differences.

Therefore, our objectives were to (1) characterize the ageing of $\mathrm{BC}$ with respect to its elemental composition, surface chemistry, and adsorption properties, and (2) identify if these changes are associated with incubation temperature and time of exposure.

\section{Materials and methods}

\subsection{BC sample}

In this study, $\mathrm{BC}$ from traditional charcoal making was used to study the ageing processes of BC. The BC sample was collected from the Hopewell Furnace National Historical Site in Pennsylvania, where charcoal making was used as a demonstration for historical charcoal production. Wood logs of white oak and red oak were used as the $\mathrm{BC}$ precursors and were stacked in a cone-shape charcoal mound, around $2 \mathrm{~m}$ in height and $2.5 \mathrm{~m}$ in diameter, and carefully charred. The charcoal-making process took $5 \mathrm{~d}$ for charring and $7 \mathrm{~d}$ for cooling. We collected the $\mathrm{BC}$ sample approximately 1 month after charring. The collected $\mathrm{BC}$ pieces were ground to 
pass through a 2-mm size sieve and stored in a sealed glass jar, purged with $\mathrm{N}_{2}$ to prevent further oxidation.

The method for making the present-day BC was the same as used by historical charcoal making during the 19th century. It was assumed that the present $\mathrm{BC}$ samples represented the timezero $\mathrm{BC}$ in comparison to the historical $\mathrm{BC}$ samples collected from historical charcoal blast furnace sites. Results of the chemical differences between the present and historical BC samples have been reported by Cheng et al. (2008a).

\subsection{Ageing experiment}

Ageing of $\mathrm{BC}$ was conducted in an aerobic incubation experiment along a temperature gradient at $-22^{\circ} \mathrm{C}, 4{ }^{\circ} \mathrm{C}, 30^{\circ} \mathrm{C}$ and $70^{\circ} \mathrm{C}$. Ten grams of $\mathrm{BC}$ were placed in a $500-\mathrm{mL}$ glass jar, to which $4 \mathrm{~mL}$ of water were added to attain a moist environment, and then incubated in the dark. Glass jars were periodically opened for aerating and checking the water content every week during the first 2 months and then every other week during the rest of the incubation. After 6 or 12 months incubation time, the glass jars were removed and dried at $70{ }^{\circ} \mathrm{C}$ for $24 \mathrm{~h}$. The incubation was conducted in duplicate and the results of chemical measurements were the average of duplicates.

In addition to the incubation, fresh $\mathrm{BC}$ coated with humic acid (Fresh BC-HA) and a historical BC sample, collected from Quebec (QC), Canada, were also obtained and used in the adsorption experiment in this study. More details on Fresh BC-HA and QC can be obtained from Cheng et al. (2008a).

\subsection{Elemental and chemical analyses}

Total $\mathrm{C}$ and nitrogen $(\mathrm{N})$ concentrations were measured by dry combustion using a Europa ANCA GSL sample combustion unit (PDZ Europa, Crewe, UK). Hydrogen $(\mathrm{H})$ concentrations were measured after conversion to $\mathrm{H}_{2}$ at $1400{ }^{\circ} \mathrm{C}$ over glassy $\mathrm{C}$ (Hekatech TCEA, Hekatech GmbH, Wegberg, Germany). Ash content was analyzed by loss of weight via combusting the BC at $550^{\circ} \mathrm{C}$ for $2 \mathrm{~h}$. Oxygen $(\mathrm{O})$ concentration was determined by difference. Elemental composition of $\mathrm{C}, \mathrm{N}, \mathrm{H}$, and $\mathrm{O}$ of $\mathrm{BC}$ samples were presented on a dry ash-free basis.

The $\mathrm{pH}$ value of $\mathrm{BC}$ was measured in $1: 20 \mathrm{w} / \mathrm{v}$ ratio in either $\mathrm{H}_{2} \mathrm{O}$ or $1 \mathrm{~N} \mathrm{KCl}$ solution. The $\mathrm{pH}$ value in $1 \mathrm{~N} \mathrm{KCl}$ presents the potential $\mathrm{pH}$, since high ionic $\mathrm{KCl}$ solution could release exchangeable protons of $\mathrm{BC}$ into solution.

Surface acidity of BC was measured by "base adsorption", whereas surface basicity was measured by "acid adsorption" (Boehm, 1994). A $0.15 \mathrm{~g}$ subsample of BC was added to $15 \mathrm{~mL}$ of either $0.1 \mathrm{~N} \mathrm{NaOH}$ or $0.1 \mathrm{~N} \mathrm{HCl}$ solution and shaken with an endover-end shaker for $30 \mathrm{~h}$. The BC slurry was then filtered using a Whatman No. 42 filter paper. An aliquot of $5 \mathrm{~mL}$ of the $\mathrm{NaOH}$ filtrate was transferred to a $10-\mathrm{mL} 0.1 \mathrm{~N} \mathrm{HCl}$ solution that neutralized the unreacted base. The solution was back-titrated with $0.1 \mathrm{~N} \mathrm{NaOH}$ against a phenolphthalein indicator. Surface basicity was measured similarly to the measurement of surface acidity and an aliquot of $5 \mathrm{~mL}$ of the HCL filtrate was directly titrated with $0.1 \mathrm{~N} \mathrm{NaOH}$. The base or acid uptake of $\mathrm{BC}$ was converted to the content of surface acidity or surface basicity (mmole $\mathrm{g}^{-1}$ ), respectively.

\subsection{Fourier transform infrared (FTIR) spectroscopy}

FTIR absorbance spectra were recorded between 400 and $4000 \mathrm{~cm}^{-1}$ with a Matteson Model 5020 FTIR Spectrometer (Madison, Wisconsin, USA). $\mathrm{KBr}$ pellets were prepared containing $0.3 \%$ of finely ground BC powder. One hundred scans from $400 \mathrm{~cm}^{-1}$ and $4000 \mathrm{~cm}^{-1}$ were averaged with a resolution of $4 \mathrm{~cm}^{-1}$.

\subsection{X-ray photoelectron spectroscopy (XPS)}

XPS measurements were conducted by using a Physical Electronics Quantum 2000 scanning ESCA Microprobe (Physical Electronics $\mathrm{GmbH}$, Ismaning, Germany). The $98-\mathrm{W}, 107-\mu \mathrm{m}$ diameter $\mathrm{X}$-rays were rastered over a 1.4 by $0.2 \mathrm{~mm}$ rectangle on the sample. High-energy resolution scan spectra of $\mathrm{C} 1 \mathrm{~s}$ and $01 \mathrm{~s}$ were recorded in $0.2 \mathrm{eV}$ steps with a pass energy of $20 \mathrm{eV}$. Low energy electrons and $\mathrm{Ar}$ ions were conducted for specimen neutralization in each measurement. Three $\mathrm{BC}$ samples, including fresh $\mathrm{BC}$ and the $\mathrm{BC}$ samples after incubation at $30^{\circ} \mathrm{C}$ and $70^{\circ} \mathrm{C}$ for 6 months, were measured. The C1s and 01s spectra were deconvoluted by a nonlinear least squares curve fitting program (XPSPEAK Version 4.1 software) and the detailed procedures are described in Cheng et al. (2008a).

\subsection{Surface charge characteristics}

The surface charge of BC samples was assessed by the "index" or "indifferent" ion adsorption method (Uehara and Gillman, 1981; Chorover et al., 2006). A KCl electrolyte $(0.01 \mathrm{~N})$ was used in the present study, in which both $\mathrm{K}$ and $\mathrm{Cl}$ ions were bound by non-specific adsorption and surface positive charge was defined as the adsorption of anions $\left(\mathrm{Cl}^{-}\right)$and surface negative charge as the adsorption of cations $\left(\mathrm{K}^{+}\right)$. Briefly, the method is comprised of three main steps: (1) preparation of a $\mathrm{KCl}$ saturated $\mathrm{BC}$ paste, (2) adjustment of the $\mathrm{pH}$ of $\mathrm{BC}$ to a range of $\mathrm{pH}$ values under the same ionic strength, and ( 3 ) displacement of adsorbed $\mathrm{K}$ and $\mathrm{Cl}$ by $1 \mathrm{~N}$ ammonium nitrate (Cheng et al., 2008a). A quadratic model was used for fitting surface charge and $\mathrm{pH}$. The point of zero net charge (PZNC) was obtained at the $\mathrm{pH}$ that had an equal amount of surface positive and negative charge. The surface charge of $\mathrm{BC}$ was presented on a $\mathrm{C}$ basis (mmole $\mathrm{kg} \mathrm{C}^{-1}$ ).

\subsection{Adsorption experiment}

To gain insights in which way ageing processes affect the adsorption capability of BC, two adsorption experiments were conducted in aqueous solution using hydroquinone. Hydroquinone was used as an example that has shown allelopathic effects on plant growth and was examined in concentrations that were occurring naturally (Chou and Muller, 1972; Weidenhamer and Romeo, 2004). First, BC samples $(0.1 \mathrm{~g})$ and $20 \mathrm{~mL}$ of a solution containing one initial concentration of $50 \mathrm{mg} \mathrm{L}^{-1}$ hydroquinone were placed in $25-\mathrm{mL}$ glass vials. The suspensions were shaken at $27^{\circ} \mathrm{C}$ for $24 \mathrm{~h}$ and then filtered through a Whatman No. 42 filter paper to remove the $\mathrm{BC}$ particles. The filter paper material was tested for hydroquinone adsorption and did not show any interference. An equilibration time of $24 \mathrm{~h}$ was found to be sufficient during preliminary experiments where no change in hydroquinone adsorption was detected beyond $12 \mathrm{~h}$ which is consistent with earlier work (Ayranci and Duman, 2005). The concentration of hydroquinone in the filtrate was analyzed by a UV-vis spectrophotometer at a wavelength of $285 \mathrm{~nm}$, and corrected for any BC passing through the filter. Here, adsorption capability of all BC samples was compared in terms of the amount of hydroquinone adsorbed by $\mathrm{BC}$ $\left(\mathrm{mg} \mathrm{g}^{-1}\right)$ at one initial concentration. Each experiment was conducted in duplicate under identical conditions and no $\mathrm{pH}$ adjustment was made.

Second, adsorption isotherms were determined for selected $\mathrm{BC}$ samples. The procedure was the same as described above, using batch solutions containing between 5 and $300 \mathrm{mg} \mathrm{L}^{-1}$ hydroquinone. Adsorption isotherms were expressed as the amount of hydroquinone adsorbed by $\mathrm{BC}\left(\mathrm{mg} \mathrm{g}^{-1}\right)$ at the equilibrium concentration and fitted according to Langmuir and Freundlich equations. The expression of the Langmuir model was: 
$q_{\mathrm{e}}=\frac{\left(q_{\max } b C_{\mathrm{e}}\right)}{\left(1+b C_{\mathrm{e}}\right)}$

where $q_{\mathrm{e}}$ is the amount of adsorbate adsorbed per unit mass of BC at equilibrium in $\mathrm{mg} \mathrm{g}^{-1}, C_{\mathrm{e}}$ is the concentration at equilibrium in $\mathrm{mg} \mathrm{L}^{-1}, q_{\mathrm{max}}$ is the maximum adsorption at monolayer coverage in $\mathrm{mg} \mathrm{g}^{-1}, b$ is the adsorption equilibrium constant. The empirical Freundlich equation is:

$q_{\mathrm{e}}=K_{\mathrm{f}} \mathrm{C}_{\mathrm{e}}^{1 / n}$

where $q_{\mathrm{e}}$ is the amount of adsorbate adsorbed per unit mass of BC at equilibrium in $\mathrm{mg} \mathrm{g}^{-1}, K_{\mathrm{f}}$ and $n$ are the Freundlich constant, and $C_{\mathrm{e}}$ is the concentration at equilibrium.

\section{Results}

\subsection{Elemental and chemical analyses}

The fresh BC showed a relatively high $\mathrm{C}$ concentration (908 $\mathrm{mg} \mathrm{g}^{-1}$ ) and low $O$ concentration $\left(68 \mathrm{mg} \mathrm{g}^{-1}\right.$ ) (Table 1 ). With the ageing of $\mathrm{BC}$, a decrease in $\mathrm{C}$ concentration and an increase in $\mathrm{O}$ concentration were observed and the magnitude of these changes increased with incubation temperature and time. In contrast, the concentrations of $\mathrm{N}$ and $\mathrm{H}$ were low and did not display differences among BC samples, except the BC samples incubated at $70{ }^{\circ} \mathrm{C}$ for which an increase in $\mathrm{H}$ content was observed.

The $\mathrm{pH}$ of fresh $\mathrm{BC}$ was 8.5 (Table 1). The $\mathrm{pH}$ values of the $\mathrm{BC}$ samples incubated at temperatures below $30^{\circ} \mathrm{C}$ decreased slightly, while the $\mathrm{pH}$ of the $\mathrm{BC}$ incubated at $70^{\circ} \mathrm{C}$ decreased substantially, from basic to acidic values. Both incubation temperature and incubation time decreased the $\mathrm{pH}$ values. The lower $\mathrm{pH}$ values in $1 \mathrm{~N}$ $\mathrm{KCl}$ solution compared to in $\mathrm{H}_{2} \mathrm{O}$ were the most distinct changes for the $\mathrm{BC}$ incubated at $70^{\circ} \mathrm{C}$ and were due to the release of exchangeable acidity in the $\mathrm{KCl}$ solution.

The change of surface acidity of BC through ageing was similar to the change in $\mathrm{pH}$, increasing with incubation temperature and incubation time (Table 1). Surface basicity showed an inverse trend that decreased with incubation temperature and time, and this value even disappeared for the $\mathrm{BC}$ incubated for 12 months at $70^{\circ} \mathrm{C}$. Overall, fresh $\mathrm{BC}$ and the $\mathrm{BC}$ samples incubated at temperatures below $30^{\circ} \mathrm{C}$ had higher surface basicity than surface acidity, while the $\mathrm{BC}$ incubated at $70^{\circ} \mathrm{C}$ showed the opposite.

\subsection{Spectroscopic analyses}

FTIR spectra showed a "flat" pattern for most BC samples and only a few poorly defined features could be identified (Fig. 1). An

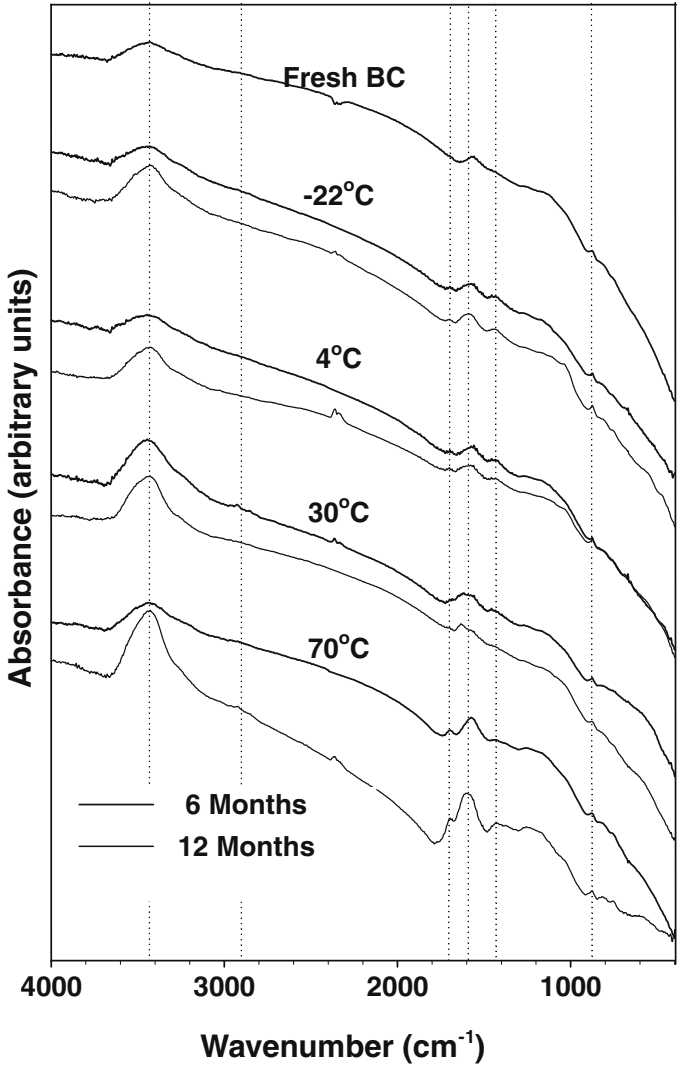

Fig. 1. Fourier transform infrared (FT-IR) spectra of fresh $B C$ and $B C$ after incubation along a temperatures gradient from $-22{ }^{\circ} \mathrm{C}$ to $70{ }^{\circ} \mathrm{C}$ for 6 and 12 months.

increase of spectra intensity and development of new surface function groups was identified for the $\mathrm{BC}$ samples incubated at $70^{\circ} \mathrm{C}$, where the bands centered at $1700 \mathrm{~cm}^{-1}$ were assigned to carboxylic $(\mathrm{COOH})$ groups, $1600 \mathrm{~cm}^{-1}$ and $1420 \mathrm{~cm}^{-1}$ were assigned to the bands of ring stretching in $\mathrm{C}=\mathrm{C}$, and $1260 \mathrm{~cm}^{-1}$ indicated the appearance of phenolic $(\mathrm{C}-\mathrm{O})$ and $\mathrm{COOH}$ groups (Cheng et al., 2008a).

Similar to FTIR spectra, XPS spectra also suggested the development of new surface functional groups for the aged BC (Fig. 2). Shifts of C1s spectra to higher binding energy for the aged BC samples indicated the formation of oxygen-containing functional groups, and shifts of $01 \mathrm{~s}$ spectra displayed increases from $\mathrm{O}-\mathrm{C}$ single bonds $(533.1 \mathrm{eV})$ to $\mathrm{O}=\mathrm{C}$ double bonds $(531.3 \mathrm{eV})$. Among the

Table 1

Elemental composition and chemical characteristics of fresh $\mathrm{BC}$ and $\mathrm{BC}$ after incubation along a temperature gradient from $-22{ }^{\circ} \mathrm{C}$ to $70{ }^{\circ} \mathrm{C}$ for 6 and 12 months.

\begin{tabular}{|c|c|c|c|c|c|c|c|c|c|c|c|}
\hline & $\begin{array}{l}\mathrm{C}^{\mathrm{a}} \\
\left(\mathrm{mg} \mathrm{g}^{-1}\right)\end{array}$ & $\begin{array}{l}\mathrm{H}^{\mathrm{a}} \\
\left(\mathrm{mg} \mathrm{g}^{-1}\right)\end{array}$ & $\begin{array}{l}\mathrm{O}^{\mathrm{a}} \\
\left(\mathrm{mg} \mathrm{g}^{-1}\right)\end{array}$ & $\begin{array}{l}\mathrm{N}^{\mathrm{a}} \\
\left(\mathrm{mg} \mathrm{g}^{-1}\right)\end{array}$ & $\begin{array}{l}\operatorname{Ash}^{\mathrm{b}} \\
\left(\mathrm{mg} \mathrm{g}^{-1}\right)\end{array}$ & $\begin{array}{l}\mathrm{pH} \\
\left(\mathrm{H}_{2} \mathrm{O}\right)\end{array}$ & $\begin{array}{l}\mathrm{pH} \\
(\mathrm{KCl})\end{array}$ & $\begin{array}{l}\text { Surface basicity } \\
\left(\mathrm{mmol} \mathrm{g}^{-1}\right)\end{array}$ & $\begin{array}{l}\text { Surface acidity } \\
\left(\mathrm{mmol} \mathrm{g}^{-1}\right)\end{array}$ & $\mathrm{PZNC}^{\mathrm{C}}$ & $\begin{array}{l}\text { Hydroquinone } \\
\text { adsorption }\left(\mathrm{mg} \mathrm{g}^{-1}\right)\end{array}$ \\
\hline Fresh BC & 908 & 22 & 68 & 2 & 19 & 8.5 & 8.4 & 0.41 & 0.13 & 7.4 & 9.61 \\
\hline $6 \mathrm{M}-22^{\circ} \mathrm{C}$ & 904 & 28 & 66 & 2 & 19 & 8.4 & 8.3 & 0.42 & 0.15 & 6.3 & 8.50 \\
\hline $6 \mathrm{M} 4^{\circ} \mathrm{C}$ & 901 & 25 & 72 & 2 & 21 & 8.5 & 8.4 & 0.39 & 0.15 & 5.8 & 9.06 \\
\hline $6 \mathrm{M} 30^{\circ} \mathrm{C}$ & 884 & 22 & 92 & 2 & 20 & 8.4 & 8.3 & 0.31 & 0.27 & 4.4 & 8.71 \\
\hline $6 \mathrm{M} 70^{\circ} \mathrm{C}$ & 871 & 29 & 98 & 2 & 16 & 7.9 & 6.0 & 0.17 & 0.59 & 3.9 & 4.93 \\
\hline $12 \mathrm{M}-22^{\circ} \mathrm{C}$ & 898 & 24 & 76 & 2 & 23 & 8.5 & 8.3 & 0.35 & 0.15 & 5.7 & 8.60 \\
\hline $12 \mathrm{M} 4^{\circ} \mathrm{C}$ & 897 & 22 & 79 & 2 & 22 & 8.6 & 8.4 & 0.27 & 0.25 & 5.4 & 9.16 \\
\hline $12 \mathrm{M} 30^{\circ} \mathrm{C}$ & 882 & 24 & 92 & 2 & 22 & 8.4 & 8.1 & 0.27 & 0.41 & 4.0 & 8.46 \\
\hline $12 \mathrm{M} 70^{\circ} \mathrm{C}$ & 858 & 34 & 106 & 2 & 19 & 6.3 & 4.1 & 0.10 & 0.88 & 2.7 & 2.65 \\
\hline Fresh $B C-H A^{d}$ & 886 & 18 & 84 & 2 & 22 & 6.0 & 6.3 & & & 6.8 & 9.08 \\
\hline $\mathrm{QC}^{\mathrm{e}}$ & 721 & 42 & 236 & 1 & 12 & 4.8 & 2.9 & & & 2.0 & 4.28 \\
\hline
\end{tabular}

a Dry ash-free basis.

b Dry basis.

c PZNC: point of zero net charge.

${ }^{d}$ Fresh BC coated with humic acid (Cheng et al., 2008a).

e Historical BC collected from Quebec, Canada (Cheng et al., 2008a). 

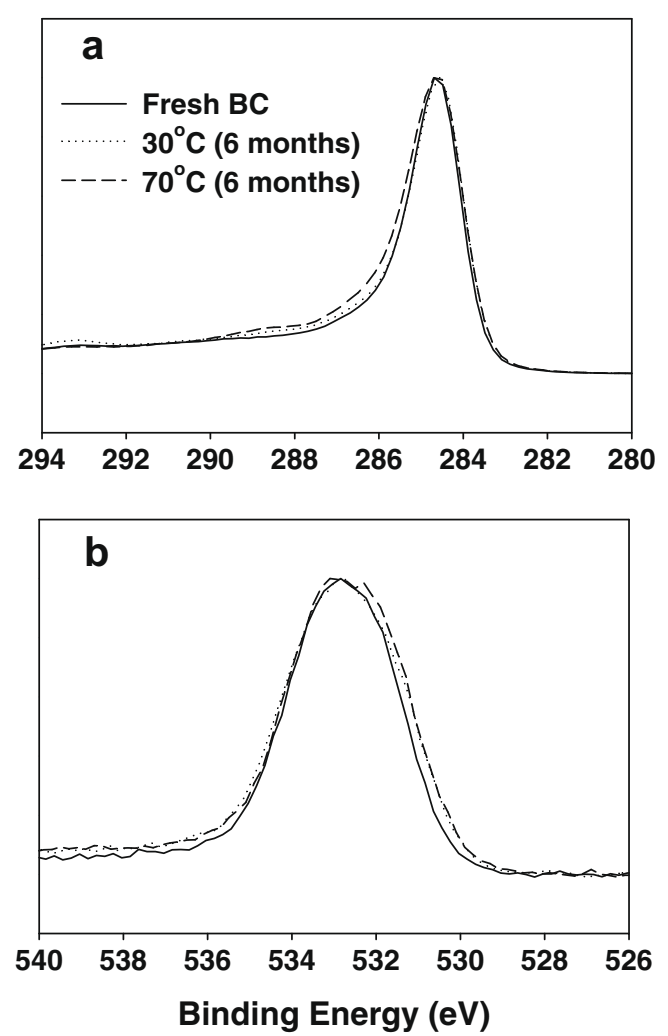

Fig. 2. X-ray photoelectron spectroscopy (XPS) spectra of C1s (a) and 01s (b) for fresh $\mathrm{BC}$ and $\mathrm{BC}$ after incubation at $30^{\circ} \mathrm{C}$ and $70{ }^{\circ} \mathrm{C}$ for 6 months.

XPS spectra, the $\mathrm{BC}$ sample incubated at $70{ }^{\circ} \mathrm{C}$ had the highest portion of $\mathrm{C}$ in $\mathrm{COO}$ groups and $\mathrm{O}$ in $\mathrm{O}=\mathrm{C}$ bonds (Table $\mathrm{S} 1$ ).

\subsection{Surface charge characteristics}

Both surface positive and negative charges for the BC samples displayed significant $\mathrm{pH}$ dependency, whereby surface positive charge decreased with increasing $\mathrm{pH}$ and surface negative charge increased with increasing $\mathrm{pH}$ (Fig. 3 and Figure S1). The fresh BC showed the highest surface positive charge and the lowest surface negative charge. Decreases of surface positive charge and increases of surface negative charge were found for the aged BC samples and these changes correlated well with both incubation temperature and incubation time. Thus, the $\mathrm{BC}$ sample incubated at $70{ }^{\circ} \mathrm{C}$ for 12 months displayed the highest surface negative charge of 200 mmole $\mathrm{kg} \mathrm{C}^{-1}$ at pH 7 and the lowest, or even negligible, surface positive charge. A strong effect of incubation temperature and incubation time on the PZNC was also observed (Table 1). The PZNC steadily decreased with higher incubation temperature and longer incubation time, from $\mathrm{pH}$ at 7.5 in fresh $\mathrm{BC}$ to $\mathrm{pH}$ at 2.7 in $\mathrm{BC}$ after incubation at $70{ }^{\circ} \mathrm{C}$ for 12 months.

\subsection{Adsorption experiments}

The fresh BC showed the highest adsorption capacity for hydroquinone (Table 1). Similar to other examined properties, only slight decreases were found for the $\mathrm{BC}$ samples incubated at temperatures below $30^{\circ} \mathrm{C}$, while a considerable reduction in adsorption capacity was observed for the $\mathrm{BC}$ incubated at $70^{\circ} \mathrm{C}$ : from $9.61 \mathrm{mg} \mathrm{g}^{-1}$ in the fresh $\mathrm{BC}$ to $2.65 \mathrm{mg} \mathrm{g}^{-1}$. Historical $\mathrm{BC}(\mathrm{QC})$ also displayed a low adsorption capacity at $4.28 \mathrm{mg} \mathrm{g}^{-1}$.

Adsorption isotherms for the aged BC samples further showed the reduction of monolayer adsorption capacity $\left(q_{\max }\right)$ and the free energy of adsorption (b) (Fig. 4 and Table S2). The fresh BC coated with $\mathrm{HA}$ did not show a reduction of adsorption at low equilibrium concentration $\left(<15 \mathrm{mg} \mathrm{L}^{-1}\right.$ ), while a reduction was observed at high equilibrium concentration. It was also observed that for highly aged $\mathrm{BC}$ samples, such as the $\mathrm{BC}$ incubated at $70^{\circ} \mathrm{C}$ for 12 months and QC, the best fitting model tended to shift from the Langmuir model to the Freundlich model.

\section{Discussion}

Our results clearly show that ageing of BC occurs over a wide temperature range from $-22^{\circ} \mathrm{C}$ to $70^{\circ} \mathrm{C}$ within a short time of 12 months. Major changes of $\mathrm{BC}$ properties through ageing can be classified into three important aspects: (i) elemental composition, (ii) surface chemistry, and (iii) adsorption characteristics.

(i) Elemental composition. Ageing of $\mathrm{BC}$ leads to increased $\mathrm{O}$ and decreased C concentrations. Puri (1970) and Cheng et al. (2006) indicated these changes in elemental composition were due to the chemisorption of oxygen onto BC surfaces through the formation of surface functional groups. $\mathrm{N}$ and $\mathrm{H}$ concentrations are relatively unchanged after the ageing process studied here, except for an increase of $\mathrm{H}$ concentrations for the highly aged $\mathrm{BC}$ samples which may be due to the formation of carboxylic and phenolic functional groups. Beyond the short-term laboratory ageing, further changes of increasing $\mathrm{O}$ and decreasing $\mathrm{C}$ concentrations are likely, as the historical BC displayed a considerable increase in $\mathrm{O}$ concentrations and decrease in $\mathrm{C}$ concentrations (Cheng et al., 2008a).

(ii) Surface chemistry. The FTIR and XPS spectra show the development of surface functional groups, especially carboxylic and phenolic structures, through BC ageing. Accordingly, surface acidity, $\mathrm{pH}$ values, surface negative charge (cation exchange capacity) and PZNC display similar trends, where surface acidity and surface negative charge are increased and values of $\mathrm{pH}$ and PZNC are reduced for aged BC. In contrast to surface acidity, surface basicity decreases with the ageing processes. Leon y Leon et al. (1992) proposed that the decrease of surface basicity was due to the incorporation of oxygen which caused a dislocation of $\pi$ electrons in the periphery of the basal planes. It is interesting to notice the disappearance of surface basicity for the highly aged $\mathrm{BC}$, such as the $\mathrm{BC}$ incubated at $70^{\circ} \mathrm{C}$ for 12 months. Long-term natural oxidation of $\mathrm{BC}$ shows similar but quantitatively more pronounced changes than the $\mathrm{BC}$ incubated at $70^{\circ} \mathrm{C}$ for 12 months, with even greater surface acidity and negligible surface positive charge (Cheng et al., 2008a).

(iii) Adsorption characteristics. For the aged BC, a decrease in adsorption capacity for hydroquinone is evident and can be explained by the increase of charge repulsion between adsorbates and $\mathrm{BC}$ surface. It is also interesting to see that the fitting models for these highly aged BC samples may indicate a shift from a Langmuir model to a Freundlich model, suggesting changes of surface complexity from homogeneous to heterogeneous surface characteristics (Cornelissen and Gustafsson, 2004), which deserve further investigation. An additional decrease is observed from the coating of BC surfaces with HA. For the BC coated with HA, the adsorption affinity at low equilibrium concentration seems to be not reduced compared to that of the fresh BC samples, which may be due to the adsorption of hydroquinone at interior pores that are not coated by the HA (Pignatello et al., 2006), whereas the reduction of maximum adsorption capacity may be due to the effects of HA on surface chemistry. It can be anticipated that both $\mathrm{BC}$ ageing and adsorption of other organic matter influence adsorption characteristics of $\mathrm{BC}$ as shown in this study.

Our results show that temperature is a critical factor in enhancing $\mathrm{BC}$ ageing. This greater $\mathrm{BC}$ ageing with higher temperature is 

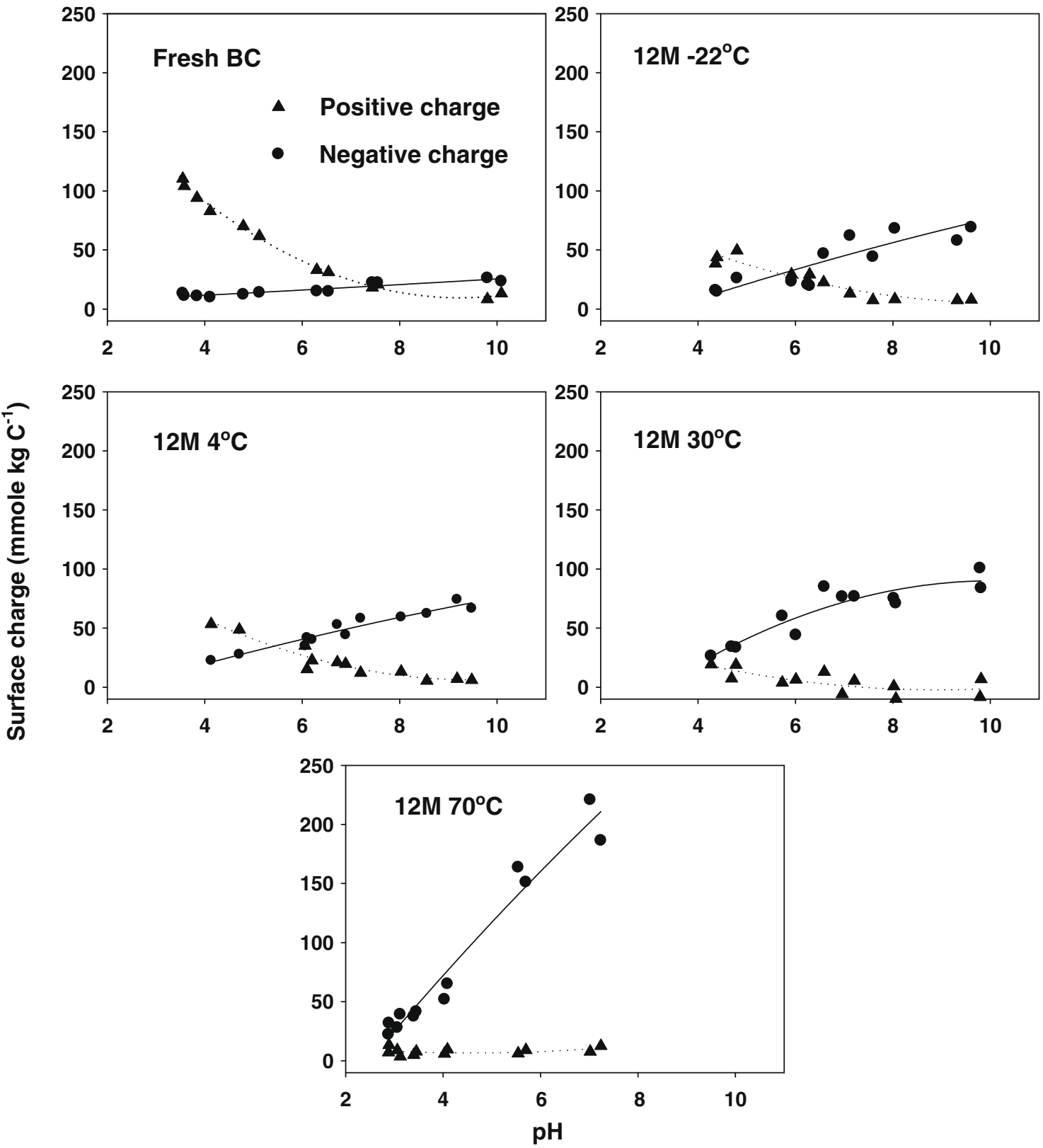

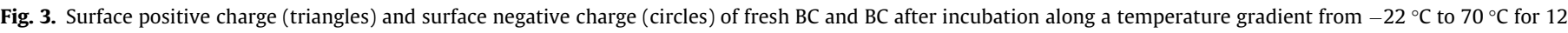
months.

likely due to the endothermic reaction of the chemisorption between oxygen and BC surfaces (Rideal and Wright, 1925; Puri, 1970; Cheng et al., 2006). As discussed above, the BC incubated at $70^{\circ} \mathrm{C}$ showed the greatest change compared to the fresh $\mathrm{BC}$, whereas the $\mathrm{BC}$ incubated at temperatures lower than $30^{\circ} \mathrm{C}$ only displayed slight changes compared to fresh BC. The temperature dependency of BC ageing seems to be non-linear and can be tentatively depicted in the Arrhenius plots on the data of surface basicity and acidity after incubation for 6 and 12 months, respectively (Figure S2). Similar results of temperature dependency following the Arrhenius equation were also reported by Allardice (1966) for short-time oxygen adsorption on BC surfaces. However, the chemical properties as shown in this study were a product of several complicated reactions, not of a single chemical reaction, and the Arrhenius equation may therefore be an oversimplification for describing the properties of BC during ageing at different temperatures. The long-term naturally oxidized BC samples also display a temperature dependency, showing a linear increase between surface charge and mean annual temperature (Cheng et al., 2008a).

It is worth noting that detectable ageing occurred even at the lowest temperature $\left(-22^{\circ} \mathrm{C}\right)$, albeit at a relatively slow rate. Similar studies of oxidation of carbonaceous materials at low temperature were also reported by Zarifyanz et al. (1967) who showed irreversible adsorption between graphite dust and oxygen at a temperature below $-40{ }^{\circ} \mathrm{C}$ and by Bansal et al. (1970) who indicated that chemisorption of oxygen on carbon black could occur at a temperature of as low as $-78^{\circ} \mathrm{C}$.

Not only the temperature but also the time of exposure affects the degree and quality of ageing. It is plausible that a certain time is required for the penetration of oxidation into interior regions of $\mathrm{BC}$ particles and for the development of functional groups, such as phenolic and carboxylic functional groups (Cheng et al., 2006). For the present study, ageing of $\mathrm{BC}$ beyond the examined time of 12 


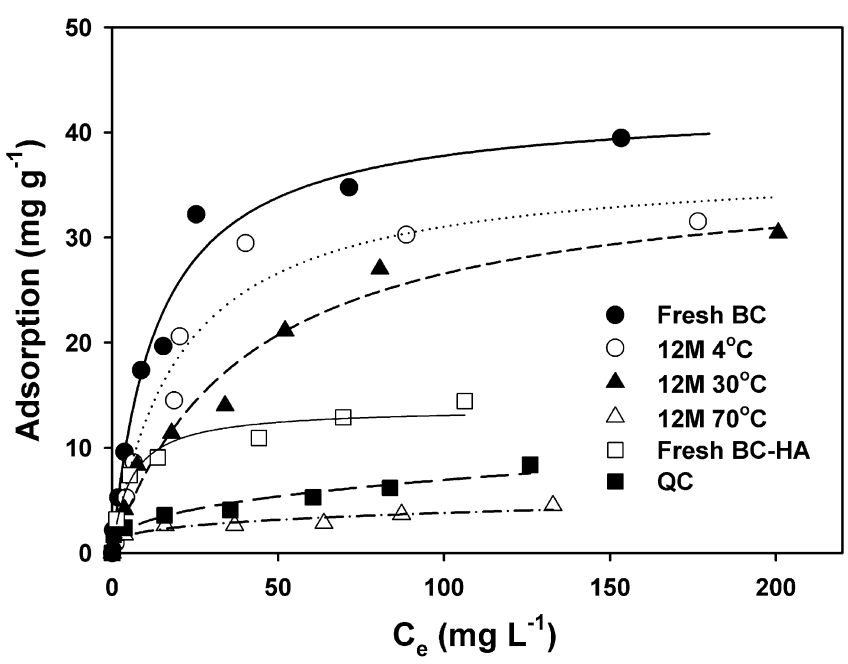

Fig. 4. Adsorption isotherms of hydroquinone to fresh $B C, B C$ after incubation at $4{ }^{\circ} \mathrm{C}, 30^{\circ} \mathrm{C}$, and $70{ }^{\circ} \mathrm{C}$ for 12 months, fresh BC coated with HA (Fresh BC-HA), and a historical $\mathrm{BC}(\mathrm{QC})$.

months is expected, as historical BC samples after 130 years of exposure in soils showed much greater oxidation (Cheng et al., 2008a).

BC collected in the present study was obtained from a kiln and produced for metallurgical purposes. From the high $\mathrm{C}$ content (90\%) and the flat FTIR spectra, it can be estimated that the BC was produced at the temperature higher than $600{ }^{\circ} \mathrm{C}$ (Nishimiva et al., 1998; Schenkel et al., 1998). Unlike this man-made BC, BC produced from forest fires or during land clearing burning for agriculture is likely to have a higher ageing rate. Firstly, a large proportion of BC from fires is produced at lower temperatures (200$600{ }^{\circ} \mathrm{C}$; Chandler et al., 1983) than the BC studied here and the rate of ageing may therefore be faster (Puri, 1961). Secondly, biotic oxidation in natural soils also enhances the ageing of BC (Fakoussa and Hofrichter, 1999). Thirdly, BC in the environment may also be oxidized by the presence of ozone (Decesari et al., 2002).

In nature, ageing of $\mathrm{BC}$ plays an important role in affecting its biogeochemical properties and global $\mathrm{BC}$ cycles. For instance, the changes in $\mathrm{BC}$ properties through ageing could then significantly influence BC's transport (Hockaday et al., 2007), erosion (Rumpel et al., 2006), stability (Masiello, 2004; Cheng et al., 2008b), or cation retention (Liang et al., 2006). Our results from a wide range of temperatures, from $-22^{\circ} \mathrm{C}$ to $70{ }^{\circ} \mathrm{C}$, suggest that ageing of $\mathrm{BC}$ is likely to occur in any terrestrial regime, which is relevant due to the ubiquitous nature of BC (Goldberg, 1985). Hence, ageing of $\mathrm{BC}$ should not be overlooked. Using fresh or newly produced $\mathrm{BC}$ as a surrogate for the study of naturally occurring $\mathrm{BC}$ may be inadequate.

\section{Conclusions}

The results clearly indicate that ageing of $\mathrm{BC}$ occurs over a wide temperature range from $-22^{\circ} \mathrm{C}$ to $70{ }^{\circ} \mathrm{C}$ within 12 months. It is also suggested that oxidation is kinetically restricted and duration is a major factor affecting ageing processes. In addition to changes in elemental composition such as increasing $\mathrm{O}$ and decreasing $\mathrm{C}$ concentrations, ageing processes can lead to the development of acidic surface functional groups resulting in lower $\mathrm{pH}$, higher surface acidity, higher negative surface charge, less surface basicity, and lower PZNC. These changes in surface chemistry further alter its adsorption characteristics, resulting in a lower adsorption capacity for substances such as hydroquinone. The results from the examined wide temperature range indicate that ageing of $\mathrm{BC}$ can occur in any terrestrial regime and that changes of $\mathrm{BC}$ properties through ageing should not be overlooked.

\section{Acknowledgements}

We thank the Hopewell Furnace National Historical Site in Pennsylvania and the Forges du Saint-Maurice National Historic Site in Quebec for permitting us to take the BC samples. We also thank Steven Ambrose, Feil Norman, Pierre Drouin, Daniel Toutant, and Chang-Ya Chen for their help with the field work. The XPS experiments were performed at the Environmental Molecular Sciences Laboratory, a national scientific user facility, located at Pacific Northwest National Laboratory, WA. We are indebted to Dr. Mark Engelhard from PNNL for help with the XPS measurements. We are very grateful for financial support from the Ministry of Education in Taiwan, the Henry Wu Scholarship, and the Keickhefer Adirondack Fellowship of Cornell University to C.H.C.

\section{Appendix A. Supplementary material}

Supplementary material associated with this article can be found, in the online version, at doi:10.1016/j.chemosphere.2009. 01.045 .

\section{References}

Allardice, D.J., 1966. The adsorption of oxygen on brown coal char. Carbon 4, 255 262.

Ayranci, E., Duman, O., 2005. Adsorption behaviors of some phenolic compounds onto high specific area activated carbon cloth. J. Hazard. Mater. 124, 125-132.

Bansal, R.C., Vastola, F.J., Walker Jr., P.L., 1970. Studies on ultraclean carbon surfaces II. Kinetics of chemisorption of oxygen on Graphon. J. Colloid Interf. Sci. 32, 187-194.

Bird, M.I., Turney, C.S.M., Fifield, L.K., Jones, R., Ayliffe, L.K., Palmer, A., Cresswell, R. Robertson, S., 2002. Radiocarbon analysis of the early archaeological site of Nauwalabila I, Arnhem Land, Australia: implications for sample suitability and stratigraphic integrity. Quaternary Sci. Rev. 21, 1061-1075.

Boehm, H.P., 1994. Some aspects of surface chemistry of carbon blacks and other carbon. Carbon 32, 759-770.

Chandler, C., Cheney, P., Thomas, P., Williams, D., 1983. Fire in Forestry. John Wiley \& Sons, New York.

Cheng, C.H., Lehmann, J., Thies, J., Burton, S.D., Engelhard, M.H., 2006. Oxidation of black carbon by biotic and abiotic processes. Org. Geochem. 37, 1477-1488.

Cheng, C.H., Lehmann, J., Engelhard, M.H., 2008a. Natural oxidation of black carbon in soils: changes in molecular form and surface charge along a climosequence. Geochim. Cosmochim. Ac. 72, 1598-1610.

Cheng, C.H., Lehmann, J., Thies, J., Burton, S.D., 2008b. Stability of black carbon in soils across a climatic gradient. J. Geophys. Res. 113, G02027.

Chorover, J., Amistadi, M.K., Chadwick, O.A., 2006. Surface charge evolution of mineral-organic complexes during pedogenesis in Hawaiian basalt. Geochim. Cosmochim. Ac. 68, 4859-4876.

Chou, C.-H., Muller, C.H., 1972. Allelopathic mechanisms of Arctostaphylos glandulos var Zacaensis. Am. Midl. Nat. 88, 324-347.

Cornelissen, G., Gustafsson, O., 2004. Sorption of phenanthrene to environmental black carbon in sediment with and without organic matter and native sorbates. Envrion. Sci. Technol. 38, 148-155.

Czimczik, C., Preston, C.M., Schmidt, M.W.I., Schulze, E., 2003. How surface fire in Siberian Scots pine forests affects soil organic carbon in the forest floor: stocks, molecular structure, and conversion to black carbon (charcoal). Global Biogeochem. Cy. 17, GB1020.

Decesari, S., Fachini, M.C., Matta, E., Mircea, M., Fuzzi, S., Chughtai, A.R., Smith, D.M., 2002. Water soluble organic compounds formed by oxidation of soot. Atmos. Environ. 36, 1827-1832.

Fakoussa, R.M., Hofrichter, M., 1999. Biotechnology and microbiology of coa degradation. Appl. Microbiol. Biotechnol. 52, 25-40.

Goldberg, E.D., 1985. Black Carbon in the Environment. John Wiley \& Sons, New York.

Hockaday, W.C., Granas, A.M., Kim, S., Hatcher, P.G., 2007. The transformation and mobility of charcoal in a fire-impacted watershed. Geochem. Cosmochim. Ac. 71, 3432-3445.

Korhola, A., Virkanen, J., Tikkanen, M., Blom, T., 1996. Fire-induced pH rise in a naturally acid hill-top lake, southern Finland: a palaeoecological survey. J. Ecol. 84, 257-265.

Lau, A.C., Furlong, D.N., Healy, T.W., Grieser, F., 1986. The electrokinetic properties of carbon black and graphitized carbon black aqueous colloids. Coll. Surf. 18 93-104.

Leon y Leon, C.A., Solar, J.M., Calemma, V., Radovic, L.R., 1992. Evidence for the protonation of basal plane sites on carbon. Carbon 30, 797-811. 
Liang, B., Lehmann, J., Solomon, D., Kinyangi, J., Grossman, J., O’Neill, B., Skjemstad, J.O., Thies, J., Luizao, F.J., Petersen, J., Neves, E.G., 2006. Black carbon increases cation exchange capacity in soils. Soil Sci. Soc. Am. J. 70, 1719-1730.

Masiello, C.A., 2004. New directions in black carbon organic geochemistry. Mar Chem. 92, 201-213.

Murage, E.W., Voroney, P., Beyaert, R.P., 2007. Turnover of carbon in the free light fraction with and without charcoal as determined using the $13 \mathrm{C}$ natural abundance method. Geoderma 138, 133-143.

Nishimiva, K., Hata, T., Imamur, Y., Ishihara, S., 1998. Analysis of chemical structure of wood charcoal by X-ray photoelectron spectroscopy. J. Wood Sci. 44, 56-61.

Pignatello, J.J., Kwon, S., Lu, Y., 2006. Effect of natural organic substances on the surface and adsorptive properties of environmental black carbon (char): attenuation of surface activity by humic and fulvic acids. Environ. Sci. Technol. 40, 7757-7763.

Puri, B.R., 1961. Surface oxidation of charcoal at ordinary temperatures. In: Proceeding of 5th Carbon Conference, pp. 165-170.

Puri, B.R., 1970. Chemistry and physics of carbon. In: Walker, P.L., Jr. (Ed.), Chemistry and Physics of Carbon. Marcel Dekker, New York, pp. 191-282.
Rideal, E.K., Wright, W.V., 1925. Low temperature oxidation at charcoal surface. Part I. The behaviour of charcoal in the absence of promoters. J. Chem. Soc. 127 1347-1357.

Rumpel, C., Chaplot, V., Planchon, O., Bernadou, J., Valentin, C., Mariotti, A., 2006 Preferential erosion of black carbon contribution on steep slopes with slash and burn agriculture. Catena 65, 30-40.

Schenkel, Y., Bertaux, P., Vanwijnbserghe, S., Carre, J., 1998. An evaluation of the mound kiln carbonization technique. Biomass Bioenergy 14, 505-516.

Schmidt, M.W.I., Noack, A.G., 2000. Black carbon in soils and sediments: analysis, distribution, implications, and current challenges. Global Biogeochem. Cy. 14, 777-793.

Uehara, G., Gillman, G., 1981. The Mineralogy, Chemistry, and Physics of Tropical Soils with Variable Charge Clays. Westview Press Inc., Boulder, CO.

Weidenhamer, J.D., Romeo, J.T., 2004. Allelochemical of Polygonella myriophylla: chemistry and soil degradation. J. Chem. Ecol. 30, 1067-1082.

Zarifyanz, Y., Kiselev, V.F., Lezhnev, N.N., Nikitina, O.V., 1967. Interaction of graphite fresh surface with different cases and vapours. Carbon 5, 127-135. 